\title{
Two COVID-19-related video-accompanied cases of severe ataxia-myoclonus syndrome
}

\author{
Filip Przytuła ${ }^{1}$, Szymon Błądek ${ }^{2}$, Jarosław Sławek ${ }^{1,3}$ \\ ${ }^{1}$ Neurology \& Stroke Department, St. Adalbert Hospital, Gdansk, Poland \\ ${ }^{2}$ Neurology \& Stroke Department, J. Korczak Specialist Hospital, Slupsk, Poland \\ ${ }^{3}$ Department of Neurological-Psychiatric Nursing, Medical University of Gdansk, Poland
}

\begin{abstract}
Aim of the study. The pandemic state of COVID-19 has resulted in new neurological post-infection syndromes. Recently, several papers have reported ataxia-myoclonus syndrome following SARS-CoV-2 infection. The aim of this study was to present our two cases and compare them to previously reported cases.

Materials and methods. We present two video-accompanied new cases with ataxia-myoclonus syndrome following SARS-CoV-2 infection and discuss the studies published so far.

Results. Ataxia-myoclonus syndrome, isolated myoclonus, opsoclonus-myoclonus syndrome as post-COVID-19 syndrome following infection have been described in 16 patients (including our two cases). Patients have been treated with intravenous immunoglobulins and/or steroids except for 4 patients, which resulted in a significant improvement within 1-8 weeks.

Conclusions and clinical implications. The increasing number of patients with a similar symptomatology shows a significant relationship between COVID-19 infection and ataxia-myoclonus syndrome. The subacute onset of neurological symptoms after a resolved COVID-19 infection and prominent response to immunotherapy may suggest that the neurological manifestations are immune-mediated. Although recovery is highly possible, it may take several weeks/months, and clinicians should be aware of this diagnosis and the beneficial effects of immunological treatment administered as soon as possible.
\end{abstract}

Key words: COVID-19, SARS-CoV-2, ataxia, myoclonus, voice tremor

(Neurol Neurochir Pol 2021; 55 (3): 310-313)

The pandemic state of COVID -19, now having lasted more than 12 months, has resulted in new clinical manifestations and neurological post-infection syndromes of SARS-CoV-2 infection, involving both central and peripheral nervous systems [1]. The most commonly occurring in the acute phase of infection include ischaemic and haemorrhagic strokes, cerebral venous thrombosis, posterior reversible encephalopathy (PRES), and those of autoimmunological origin presenting as Guillain-Barre, Miller Fisher syndromes and Bickerstaff's encephalitis, acute demyelinating encephalomyelitis (ADEM), acute necrotising encephalopathy (ANE), generalised myoclonus, acute transverse myelitis, limbic encephalitis, and miscellaneous encephalitis $[1,2]$. Recently, several papers have reported ataxia-myoclonus syndrome following SARS-CoV-2 infection (Tab. 1) [6-12]. We present two video-accompanied new cases of this presumably autoimmunological syndrome.

\section{Case 1}

A 49-year-old male, without co-morbidities besides lumbar surgery eight years previously, was admitted to hospital with involuntary movements of limbs and trunk accompanied by severe instability (he was almost unable to stand or walk independently). Eleven days before admission, the patient had experienced an episode of one-day fever $\left(38^{\circ} \mathrm{C}\right)$ with excessive sweating without any other infection symptoms. These symptoms resolved spontaneously after a few days and he was not tested for COVID-19 infection. One week later, he developed hand tremors, jerky movements of all limbs, 
Table 1. Characteristics of patients with ataxia-myoclonus syndrome associated with COVID-19

\begin{tabular}{|c|c|c|c|c|c|}
\hline Article & $\begin{array}{l}\text { Age/ } \\
\text { /gender }\end{array}$ & $\begin{array}{l}\text { COVID-19 } \\
\text { severity of } \\
\text { infectious } \\
\text { stage }\end{array}$ & $\begin{array}{l}\text { Neurological } \\
\text { symptoms }\end{array}$ & $\begin{array}{l}\text { Time between acute } \\
\text { infection and } \\
\text { appearance } \\
\text { of neurological } \\
\text { symptoms }\end{array}$ & Treatment/outcome \\
\hline \multirow[t]{2}{*}{ Our cases } & $49 / M$ & $\begin{array}{l}\text { Mild/ } \\
\text { asymptomatic }\end{array}$ & $\begin{array}{l}\text { - Myoclonus } \\
\text { - Ataxia } \\
\text { - Voice tremor }\end{array}$ & 11 days & $\begin{array}{l}\text { Methyloprednisolone } 1 \mathrm{~g} / \text { day, } 5 \mathrm{~g} \text { total followed by } \\
\text { oral prednisone } 60 \mathrm{mg} / \text { day for two weeks; } \\
\text { significant improvement after three weeks }\end{array}$ \\
\hline & $62 / M$ & Mild & $\begin{array}{l}\text { - Myoclonus } \\
\text { - Opsoclonus } \\
\text {-Ataxia }\end{array}$ & 11 days & $\begin{array}{l}\text { IVIG } 0.4 \mathrm{~g} / \mathrm{kg} \text { for five days, } \\
\text { methyloprednisolone } 1 \mathrm{~g} / \text { day, } 5 \mathrm{~g} \text { total followed by } \\
\text { oral prednisone ( } 1 \mathrm{mg} / \mathrm{kg} / \text { day) for two weeks with } \\
\text { gradual dose reduction; significant improvement } \\
\text { after two weeks }\end{array}$ \\
\hline \multirow[t]{7}{*}{$\begin{array}{l}\text { Emamik- } \\
\text { hah et al. } \\
2021[6]\end{array}$} & $51 / \mathrm{M}$ & Mild & $\begin{array}{l}\text { - Myoclonus } \\
\text { - Opsoclonus } \\
\text { - Ataxia } \\
\text { - voice tremor }\end{array}$ & 2 weeks & $\begin{array}{l}\text { Clonazepam } 0.5 \mathrm{mg} 4 \times 1 \text {, levetiracetam } 500 \mathrm{mg} 2 \text { × } 1 \text {, } \\
\text { IVIG } 2 \mathrm{~g} / \mathrm{kg} \text {, total dose } 150 \mathrm{~g} \text {; } \\
\text { complete recovery after four weeks }\end{array}$ \\
\hline & $54 / \mathrm{M}$ & Moderate & $\begin{array}{l}\text { - Myoclonus } \\
\text {-Ataxia }\end{array}$ & 4 days & $\begin{array}{l}\text { Levetiracetam 2,000 mg/day, sodium valproate } \\
1,000 \mathrm{mg} / \text { day } \\
\text { IVIG in total dose } 100 \mathrm{~g} \text {; Partial recovery after } \\
\text { one week }\end{array}$ \\
\hline & $52 / \mathrm{M}$ & Moderate & $\begin{array}{l}\text { - Myoclonus } \\
\text { - Ataxia } \\
\text { - Voice tremor }\end{array}$ & 16 days & $\begin{array}{l}\text { Sodium valproate } 1,000 \mathrm{mg} / \text { day. } \\
\text { clonazepam } 1 \mathrm{mg} 4 \times 1 \\
\text { partial recovery after two months }\end{array}$ \\
\hline & $42 / F$ & Mild & $\begin{array}{l}\text { - Myoclonus } \\
\text { - Ataxia } \\
\text { - Voice tremor }\end{array}$ & 10 days & $\begin{array}{l}\text { Sodium valproate, } \\
\text { clonazepam; } \\
\text { no data }\end{array}$ \\
\hline & $44 / \mathrm{M}$ & Mild & $\begin{array}{l}\text { - Myoclonus } \\
\text { - Opsoclonus } \\
\text { - Ataxia } \\
\text { - Voice tremor }\end{array}$ & 3 days & $\begin{array}{l}\text { Sodium valproate, clonazepam, IVIG; complete } \\
\text { recovery after two months }\end{array}$ \\
\hline & $52 / \mathrm{M}$ & Mild & $\begin{array}{l}\text { - Myoclonus } \\
\text { - Ataxia } \\
\text { - Voice tremor }\end{array}$ & 3 weeks & $\begin{array}{l}\text { Clonazepam, IVIG in total dose of } 100 \mathrm{~g} \text {; significant } \\
\text { improvement after four weeks }\end{array}$ \\
\hline & $39 / M$ & Severe & $\begin{array}{l}\text { - Myoclonus } \\
\text { - Opsoclonus } \\
\text { - Ataxia } \\
\text { - Voice tremor }\end{array}$ & 10 days & $\begin{array}{l}\text { Levetiracetam, sodium valproate, clonazepam, } \\
\text { IVIG, dexamethasone; no data }\end{array}$ \\
\hline $\begin{array}{l}\text { Wright } \\
\text { et al. } 2020 \\
\text { [7] }\end{array}$ & $79 / M$ & Mild & $\begin{array}{l}\text { - Opsoclonus } \\
\text { - Ataxia } \\
\text { - Cognitive impairment }\end{array}$ & 13 days & $\begin{array}{l}\text { No data; improvement of cognitive function and re- } \\
\text { solution of eye movement abnormality after } 19 \text { days; } \\
\text { death after } 27 \text { days due to general physical decline }\end{array}$ \\
\hline $\begin{array}{l}\text { Dijkstra } \\
\text { et al. } 2020 \\
{[8]}\end{array}$ & $44 / \mathrm{M}$ & Mild & $\begin{array}{l}\text { - Myoclonus } \\
\text { - Ataxia } \\
\text { - Voice tremor } \\
\text { - Transient ocular flutter } \\
\text { (no evident opsoclonus) } \\
\text { - Cognitive impairment }\end{array}$ & 1 week & $\begin{array}{l}\text { Methyloprednisolone } 1 \mathrm{~g} \text { daily for five days, } \\
\text { IVIG } 0.4 \mathrm{~g} / \mathrm{kg} \text { for three days; partial recovery after } \\
15 \text { days, full recovery within two months }\end{array}$ \\
\hline $\begin{array}{l}\text { Schel- } \\
\text { lekens } \\
\text { et al. } 2020 \\
\text { [9] }\end{array}$ & $48 / \mathrm{M}$ & Mild & $\begin{array}{l}\text { - Myoclonus } \\
\text { - Ataxia } \\
\text { - Saccadic intrusions of eye } \\
\text { movement (no opsoclo- } \\
\text { nus) }\end{array}$ & 13 days & Levetiracetam; partial recovery within two months \\
\hline \multirow[t]{2}{*}{$\begin{array}{l}\text { Foucard } \\
\text { et al. [10] }\end{array}$} & $83 / \mathrm{M}$ & No data & $\begin{array}{l}\text { - Myoclonus } \\
\text { - Opsoclonus } \\
\text { - Ataxic dysarthria } \\
\text { - Confusion }\end{array}$ & 10 days & $\begin{array}{l}\text { IVIG } 0.4 \mathrm{~g} / \mathrm{kg} \text { for five days, steroids } 1 \mathrm{~g} / \text { day for five } \\
\text { days, diazepam; significant improvement after one } \\
\text { week }\end{array}$ \\
\hline & $63 / \mathrm{M}$ & No data & $\begin{array}{l}\text { - Myoclonus } \\
\text {-Ataxia } \\
\text {-Ataxic dysarthria }\end{array}$ & 6 weeks & $\begin{array}{l}\text { IVIG } 0.4 \mathrm{~g} / \mathrm{kg} \text { for five days; significant improvement } \\
\text { after one week }\end{array}$ \\
\hline $\begin{array}{l}\text { Shah } \\
\text { et al. } 2020 \\
{[11]}\end{array}$ & $\begin{array}{l}\text { Middle } \\
\text { aged/M }\end{array}$ & No data & $\begin{array}{l}\text { - Myoclonus } \\
\text { - Opsoclonus } \\
\text {-Ataxia } \\
\text {-Ataxic dysarthria }\end{array}$ & 3 weeks & $\begin{array}{l}\text { Methylprednisolone } 1 \mathrm{~g} / \text { day, sodium valproate } \\
20 \mathrm{mg} / \mathrm{kg} / \text { day, clonazepam } 2 \mathrm{mg} / \text { day, levetiracetam } \\
2 \mathrm{~g} / \text { day; recovery within one week }\end{array}$ \\
\hline $\begin{array}{l}\text { Grimaldi } \\
\text { et al. } 2020 \\
{[5]}\end{array}$ & $72 / \mathrm{M}$ & Moderate & $\begin{array}{l}\text { - Myoclonus } \\
\text {-Ataxia } \\
\text {-Ataxic dysarthria }\end{array}$ & 17 days & $\begin{array}{l}\text { IVIG } 0.4 \mathrm{~g} / \mathrm{kg} / \text { day for five days, methyloprednisolone } \\
1 \mathrm{~g} / \text { day for five days; recovery within two weeks }\end{array}$ \\
\hline
\end{tabular}


and posture and gait instability with diarrhoea lasting for three days. Because of these symptoms, he was admitted to the Emergency Unit (EU). On neurological examination, he presented dysarthria with voice tremor, generalised myoclonus exacerbated by intentional movements, bilateral limb ataxia and wide-based gait (see video, segment 1). In the EU he was treated with clonazepam $1 \mathrm{mg}$ i.v., biperiden $2 \mathrm{mg}$ p.o. and levetiracetam $500 \mathrm{mg}$ i.v. but with no effect. Nasopharyngeal RT-PCR test for SARS-CoV-2 was negative. Brain computer tomography (CT) and magnetic resonance imaging (MRI), as well as a general examination of cerebrospinal fluid (CSF), were normal. Antibodies testing (blood and CSF) for NMDAR, VGKC, Borrelia burgdorferi IgG and IgM antibodies were negative. Viral neurological panel (Adenovirus, CMV, EBV, HSV-1, HSV-2, VZV, Enterovirus, Parechovirus, Parvovirus B19, HHV-6, HHV-7) and soluble antigens in CSF were also negative. Oligoclonal bands in CSF showed type 4 according to the Charcot Foundation. Blood laboratory tests for onconeural antibodies (anti-Hu, anti-Ri, Anti-Yo), anti-nuclear antibodies (ANA) were negative, and vitamin B12, B1 and folic acid were within normal ranges.

Due to the infection episode 11 days before admission, serum level of SARS-CoV-2 IgG and IgM antibodies testing was performed, with a positive result for $\operatorname{IgG}(\operatorname{IgG} 38.6 \mathrm{AU} / \mathrm{ml}$, IgM $2.2 \mathrm{AU} / \mathrm{ml}$ ). Treatment with intravenous methyloprednisolone ( $1 \mathrm{~g} /$ day for five consecutive days, $5 \mathrm{~g}$ in total) followed by oral prednisone $(60 \mathrm{mg} /$ day $)$ for two weeks and motor rehabilitation resulted in a significant improvement after three weeks (see video, segment 2).

\section{Case 2}

A 62-year-old male with a history of arterial hypertension, benign prostatic hyperplasia, and kidney stones, was, 11 days after resolution of a COVID-19 infection confirmed with a nasopharyngeal RT-PCR test, admitted to the EU with imbalance, gait disturbance, generalised tremor and ataxia. On neurological examination, he had jerky oscillatory movements of eyes (diagnosed as opsoclonus), generalised myoclonus and ataxia. This made the patient unable to stand or walk independently (see video, segment 3). Head MRI with MRIangiography as well as general CSF examination were normal. Fast CSF tests for the presence of viral (CMV, Enterovirus, HSV-1, HSV-2, HHV-6, Parechovirus, VZV) and bacterial (E. coli, H. influenzae, L. monocytogenes, N. meningitidis, S. agalactiae, S. pneumoniae) antigens were negative as well. Auto-immune encephalitis antibodies in serum (NMDAR, AMPAR 1 and 2, CASPR 2, LGI-1, GABA-B receptor), Borrelia IgM and IgG antibodies and onconeural antibodies (anti- $\mathrm{Hu}$, anti-Ri, Anti-Yo, anti-PNMA2, anti-CV2, anti-amphiphysin) were not detected. Ganglioside antibody panel was negative. Chest and abdomen CT were normal. Tumour markers (CA-125, CA-19-9, CEA) were negative. Electroencephalography (EEG) on admission showed bilateral theta waves in the central and frontal areas which resolved at release. Treatment with intravenous methyloprednisolone ( $1 \mathrm{~g} / \mathrm{day}, 5 \mathrm{~g}$ in total) was initiated followed by intravenous immunoglobulins (IVIG) for five days $(0.4 \mathrm{~g} / \mathrm{kg})$ and oral prednisone $(1 \mathrm{mg} / \mathrm{kg} / \mathrm{day})$ for two weeks with gradual dose reduction. The administered treatment and motor rehabilitation resulted in a significant improvement after two weeks (see video, segment 4).

\section{Discussion}

Understanding regarding the neurological complications of SARS-CoV- 2 infection is still limited. Brain damage can be caused by hypoxia, direct brain invasion of the coronavirus, or post-infectious autoimmune mechanisms. The hypothesis of a possible neuroinvasiveness of SARS-CoV-2 causing neurological symptoms during the acute state of the infection has been proposed [2]. Widespread neuronal ACE2 expression in brainstem cardiorespiratory neurons, motor cortex, the raphe nucleus, and others may suggest the direct invasion of virus, which may result in diverse neurological symptoms.

While ACE2's role in the brain is incompletely understood, this diverse central nervous expression pattern may provide SARS-CoV-2, and other CoVs, with a 'port of entry' into the brain [3]. On the other hand, opsoclonus-myoclonus syndrome (OMS) is a rare disorder of apparently autoimmune paraneoplastic or parainfectious aetiology. This presents with opsoclonus, limbs and trunk myoclonus, and ataxia. Paraneoplastic OMS is generally observed in patients with breast adenocarcinoma or small cell lung carcinoma, while parainfectious OMS has been observed in patients with HIV, Mycoplasma pneumoniae, Salmonella enterica, rotavirus, cytomegalovirus, human herpesvirus 6, hepatitis $C$, and Rickettsia conorii. Treatment with corticosteroids or IVIG is usually successful [4]. Therefore, its aetiology is considered to be autoimmunological.

The subacute onset of neurological symptoms after resolved COVID-19 infections (however, only 11 days after) in both presented cases, and the prominent response to immunotherapy, may suggest that the neurological manifestations are immune-mediated. However, it is difficult to entirely exclude a direct viral effect of COVID-19, given that we know that acute COVID infection can benefit from steroids. The brain ${ }^{18}$ F-FDG-PET (fluorodeoxyglucose Positron Emission Tomography) study of a patient with ataxia-myoclonus syndrome associated with COVID-19 performed by Grimaldi et al. showed a diffuse pattern compatible with encephalitis and especially cerebellitis. Moreover, nerve tissue immunostaining with serum and CSF showed the presence of autoantibodies directed against the nuclei of Purkinje cells, striatal and hippocampal neurons. The titre of the $\operatorname{IgG}$ autoantibodies in serum and CSF was high (serum 1/25,000, CSF 1/96) and both in serum and CSF the same intensity and reactivity were observed at the same IgG concentration [5]. These observations may confirm the autoimmune origin of the post-COVID-19 ataxia-myoclonic syndrome. 
Ataxia-myoclonus syndrome, isolated myoclonus, OMS as post-COVID-19 syndrome following infection have been described in several case series and reports (Tab. 1). The increasing number of patients with a similar symptomatology suggests that there may be a significant relationship between infection and the described neurological symptoms, adding SARS-CoV-2 to the list of possible pathogens. Because recovery is highly possible, although it may take several weeks/ /months, clinicians should be aware of this diagnosis and the beneficial effects of immunological treatment administered as soon as possible.

\section{References}

1. Maury A, Lyoubi A, Peiffer-Smadja N, et al. Neurological manifestations associated with SARS-CoV-2 and other coronaviruses: A narrative review for clinicians. Rev Neurol (Paris). 2021; 177(1-2): 51-64, doi: 10.1016/j.neurol.2020.10.001, indexed in Pubmed: 33446327.

2. Słyk S, Domitrz I. Neurological manifestations of SARS-CoV-2 - a systematic review. Neurol Neurochir Pol. 2020; 54(5): 378-383, doi: 10.5603/PJNNS.a2020.0050, indexed in Pubmed: 32667047.

3. Tipton PW, Wszolek ZK. What can Parkinson's disease teach us about COVID-19? Neurol Neurochir Pol. 2020; 54(2): 204-206, doi: 10.5603/PJNNS.a2020.0039, indexed in Pubmed: 32323862.

4. Oh SY, Kim JS, Dieterich M. Update on opsoclonus-myoclonus syndrome in adults. J Neurol. 2019; 266(6): 1541-1548, doi: 10.1007/ s00415-018-9138-7, indexed in Pubmed: 30483882.
5. Grimaldi S, Lagarde S, Harlé JR, et al. Autoimmune Encephalitis Concomitant with SARS-CoV-2 Infection: Insight from F-FDG PET Imaging and Neuronal Autoantibodies. J Nucl Med. 2020; 61(12): 1726-1729, doi: 10.2967/jnumed.120.249292, indexed in Pubmed: 32709734.

6. Emamikhah M, Babadi M, Mehrabani M, et al. Opsoclonus-myoclonus syndrome, a post-infectious neurologic complication of COVID-19: case series and review of literature. J Neurovirol. 2021; 27(1): 26-34, doi: 10.1007/s13365-020-00941-1, indexed in Pubmed: 33492608.

7. Wright D, Rowley R, Halks-Wellstead P, et al. Abnormal Saccadic Oscillations Associated with Severe Acute Respiratory Syndrome Coronavirus 2 Encephalopathy and Ataxia. Mov Disord Clin Pract. 2020; 7(8): 980-982, doi: 10.1002/mdc3.13101, indexed in Pubmed: 33163571.

8. Dijkstra F, Van den Bossche T, Willekens B, et al. Myoclonus and cerebellar ataxia following Coronavirus Disease 2019 (COVID-19). Mov Disord Clin Pract. 2020 [Epub ahead of print], doi: 10.1002/ mdc3.13049, indexed in Pubmed: 32837962.

9. Schellekens MMI, Bleeker-Rovers CP, Keurlings PAJ, et al. Reversible Myoclonus-Ataxia as a Postinfectious Manifestation of COVID-19. Mov Disord Clin Pract. 2020; 7(8): 977-979, doi: 10.1002/mdc3.13088, indexed in Pubmed: 33163570.

10. Foucard C, San-Galli A, Tarrano C, et al. Acute cerebellar ataxia and myoclonus with or without opsoclonus: a parainfectious syndrome associated with COVID-19. Eur J Neurol. 2021 [Epub ahead of print], doi: 10.1111/ene.14726, indexed in Pubmed: 33492711.

11. Shah PB, Desai SD. Opsoclonus Myoclonus Ataxia Syndrome in the Setting of COVID-19 Infection. Neurology. 2021; 96(1): 33, doi: 10.1212/ WNL.0000000000010978, indexed in Pubmed: 33004603. 